\title{
The Effect of Perceived Value and Personal Selling on Participants 'Decision on Employment BPJS Bengkulu Branch (Case Study on Wage Non- Recipient Category Customers)
}

\author{
Nurhidayati, Zakaria Wahab, Dan Marlina Widiyanti
}

\begin{abstract}
The purpose of this study was to determine the effect of perceived value and personal selling on participants' decisions on BPJS Employment in the category of Non Wage Recipients (NRP). The population in this study were all BPJS Employment participants in the Non Wage category during 2018. The sample in this study was 100 respondents. The analysis technique in this study used multiple linear regression analysis. The results of this study indicate that the variables perceived value and personal selling jointly influence the decisions of the BPJS Employment participants. Perceived value has a positive and significant effect on participants' decisions and personal selling has a positive and significant effect on the decisions of BPJS Employment participants.
\end{abstract}

Keywords: Perceived Value, Personal Selling, Participants Decisions

\section{INTRODUCTION}

The social security of workers should indeed be the right for every worker. In implementing this social security program BPJS Employment is governed by Law No. 24 of 2011 Chapter $\mathrm{V}$ Article 14 which states that all workers in Indonesia are required to become participants in the BPJS Employment, not least for foreign nationals who are domiciled and working in Indonesia.

Table 1. Data on the Number of Registered Participants in BPJS Employment

\begin{tabular}{ccccc}
\hline No & $\begin{array}{c}\text { Type of } \\
\text { Participation }\end{array}$ & Total (2016) & $\begin{array}{c}\text { Total } \\
\text { (2017) }\end{array}$ & $\begin{array}{c}\text { Total } \\
\mathbf{( 2 0 1 8 )}\end{array}$ \\
\hline 1 & $\begin{array}{c}\text { Participation } \\
\text { PU }\end{array}$ & 38.002 & 38.243 & 38.579 \\
& $\begin{array}{c}\text { Participation } \\
\text { NRP }\end{array}$ & 3.184 & 13.479 & 16.710 \\
\hline
\end{tabular}

Source: BPJS Employment Bengkulu Branch

Data on the management of the BPJS Employment program for 2017 - 2018 shows that the achievement of the participation target of Wage Non-Recipient (NRP) workers is still relatively very low compared to the category of BPJS Employment participants in the category of Wages (PU). This is because NRP participants are the most objective and dynamic BPJS consumers in using social security services from BPJS.

Revised Manuscript Received on August 15, 2019.

* Correspondence Author

Nurhidayati*, Magister Management, Economic Faculty, University of Sriwijaya E-mail: nurhidayatibpjstk@gmail.com

Zakaria Wahab, Magister Management, Economic Faculty, University of Sriwijaya

Dan Marlina Widiyanti, Magister Management, Economic Faculty, University of Sriwijaya

(C) The Authors. Published by Blue Eyes Intelligence Engineering and Sciences Publication (BEIESP). This is an open access article under the CC BY-NC-ND license (http://creativecommons.org/licenses/by-nc-nd/4.0/)
The selection of this program is not suppressed by government regulations such as the BPJS Employment program in the PU category. BPJS Employment Participants in the NRP category register their participation in their own decisions without intervention or coercion from other parties or binding rules. This means that participants in this category have the ability to decide for themselves objectively whether or not to use employment social security services from BPJS Employment in accordance with their respective perceptions. The following is the recapitulation of the membership of Bengkulu Employment BPJS in the category of Non Wage Recipient (NRP) participants with status (active).

Table 2. BPJS Employment Participation in NRP Category (Active)

\begin{tabular}{|c|c|c|c|c|}
\hline No & $\begin{array}{c}\text { Type of } \\
\text { Participation }\end{array}$ & $\begin{array}{l}\text { Total / } \\
\text { (2016) }\end{array}$ & $\begin{array}{l}\text { Total / } \\
\text { (2017) }\end{array}$ & $\begin{array}{l}\text { Total / } \\
(2018)\end{array}$ \\
\hline 1 & $\begin{array}{c}\text { Participation } \\
\text { NRP }\end{array}$ & 994 & 2,151 & 1,093 \\
\hline \multirow{2}{*}{\multicolumn{2}{|c|}{$\begin{array}{l}\text { The amount of } \\
\text { difference } \\
\text { Information }\end{array}$}} & - & 1,157 & 1,058 \\
\hline & & - & $(+)$ & $(-)$ \\
\hline \multicolumn{2}{|c|}{ Percentage } & $100 \%$ & $53.79 \%$ & $49.19 \%$ \\
\hline
\end{tabular}

Based on Table 2, can be seen in the period 2016 - 2017 there was an increase in active participation in the NRP category by (53.79\%). Furthermore, in the 2017 - 2018 period there was a significant decline, which was equal to (49.19\%). The decline in participation is a challenge for the Bengkulu BPJS Employment Branch so that in the future it can encourage participation in this NRP category to be more productive such as participation in the PU category. In the category of membership of Non Wage Recipients (NRP), BPJS Employment has three types of employment social security programs. The following are the programs offered in the category of Non-Wage Recipients (NRP) BPJS Employment participants. 
The Effect of Perceived Value and Personal Selling on Participants 'Decision on Employment BPJS Bengkulu Branch (Case Study on Wage Non-Recipient Category Customers)

Table 3. Types of Non-Wage Recipient Programs (NRP)

\begin{tabular}{|c|c|c|}
\hline No & Type of Program & Functionality \& Usability \\
\hline 1 & $\begin{array}{l}\text { Accident } \\
\text { Insurance (AI) }\end{array}$ & $\begin{array}{l}\text { Provide protection for the risks } \\
\text { of accidents that occur in } \\
\text { employment relationships, } \\
\text { including accidents that occur } \\
\text { during the journey from home } \\
\text { to the place }\end{array}$ \\
\hline 2 & $\begin{array}{l}\text { Life Insurance } \\
\text { (LI) }\end{array}$ & $\begin{array}{l}\text { Providing benefits of cash } \\
\text { given to heirs when participants } \\
\text { die not due to workplace } \\
\text { accidents }\end{array}$ \\
\hline 3 & $\begin{array}{l}\text { Pansion Plan } \\
\text { (PP) }\end{array}$ & $\begin{array}{l}\text { The benefits of JHT are in the } \\
\text { form of cash, the amount of } \\
\text { which is the accumulated value } \\
\text { of contributions plus the results } \\
\text { of development }\end{array}$ \\
\hline
\end{tabular}

Source: www.bpjsketenagakerjaan.go.id

In Table 3, it can be seen the classification of program types and their functions and uses in the category of Non Wage Recipients (NRP) participants. In carrying out the workforce social security program, Employment BPJS always improves service to participants of the Non Wage Recipient (NRP) participant category. Through the realization of claims that are processed quickly and on time and provide other additional service benefits, for example, providing special discounts at merchants who have collaborated with BPJS Employment. BPJS Employment hopes that the community or participants in the NRP category can truly feel the maximum benefit from the services provided by BPJS Employment.

BPJS Employment participants, especially the category of Non Wage Recipients (NRP), are potential customers who want the quality of services offered by BPJS Employment to be improved in the future. Service quality is related to meeting the expected needs of consumers so that it can trigger decision making. This is in accordance with the opinion of Tjiptono (2009: 59) which states that, service quality is the expected level of excellence and control of the level of excellence to meet customer desires. Tjiptono and Chandra (2009: 119) state that service excellence can be formed through the integration of four pillar service excellence that are closely related, namely: speed, accuracy, friendliness and convenience of service. To review the quality of BPJS Employment services, The following shows the satisfaction index of the Bengkulu Branch BPJS Employment participants for several current periods which can be seen in Figure 1.

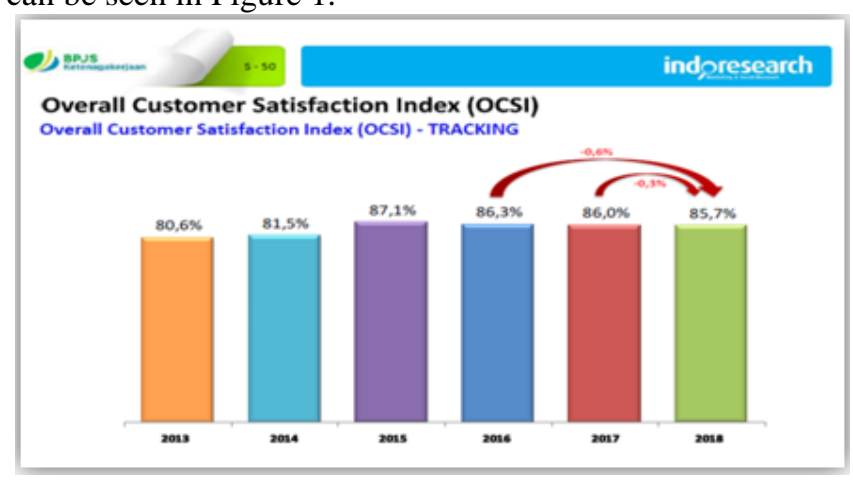

Source: BPJS Employment Bengkulu Branch

Figure 1. Customer Satisfaction Index

Retrieval Number L03290831219/2019@BEIESP

DOI: 10.35940/ijmh.L0329.0831219

Journal Website: www.ijmh.org

Published By:

Blue Eyes Intelligence Engineering \& Sciences Publication

(C) Copyright: All rights reserved.

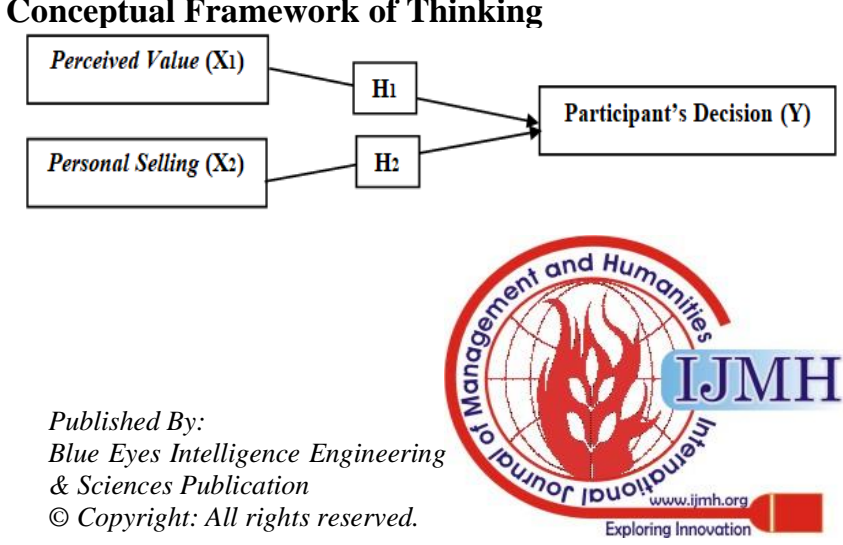




\section{RESEARCH METHODS}

1. Variable X (Free Variable), namely perceived value and personal selling

2. Variable Y (Bound Variables), namely the decision of the participant

The population in this study were all participants of the Bengkulu Branch BPJS Employment in the category of Non-Wage Recipient (NRP) participants in 2018.

Table 4. Number of BPJS Employment Participants in the Old Age Insurance Program NRP Category

\begin{tabular}{lllll}
\hline No. & Type of Participants & Total (2016) & Total (2017) & Total (2018) \\
\hline 1 & Participants NRP & 994 & 2,151 & 1,093 \\
& The amount of difference & - & 1,157 & 1,058 \\
& Information & - & $(+)$ & $(-)$ \\
\hline & Percentage & $\mathbf{1 0 0 \%}$ & $\mathbf{5 3 , 7 9 \%}$ & $\mathbf{4 9 , 1 9 \%}$ \\
\hline
\end{tabular}

Slovin included an element of inaccuracy due to sampling errors that could still be tolerated. This tolerance value is expressed as a percentage, for example $10-20 \%$ The formula used is as follows:

$\mathbf{n}=\frac{\mathbf{n}}{\mathbf{1}+\mathbf{N e}^{2}}$

$\mathrm{n}$ = sample size; $\mathrm{N}$ = population size; and $\mathrm{e} 2$ = Tolerance of inaccuracy

$\mathrm{n}=\frac{\mathrm{n}}{1+\mathrm{Ne}^{2}}$

$\mathrm{n}=\frac{1.058}{1+1.058(0,1)^{2}}$

$\mathrm{n}=91,36$

Based on the sample calculation above, the sample to be used in this study is 91.36 which is rounded up to 100 respondents who are BPJS Employment participants in the Old Age Insurance Program (BPU) BPU category. The sample used in this study were 150 respondents.

IV. RESULTS AND DISCUSSION

Table 5. Reliability Test

\begin{tabular}{lllll}
\hline \multicolumn{1}{c}{ Variable } & $\begin{array}{c}\text { Cronbach's } \\
\text { Alpha }\end{array}$ & Cutt Off & N of Item & \multicolumn{1}{c}{ Information } \\
\hline Perceived Value (X1) & 0,718 & $>0,60$ & 10 & Reliable \\
Personal Selling (X2) & 0,721 & $>0,60$ & 10 & Reliable \\
Participants Dicision (Y) & 0,667 & $>0,60$ & 10 & Reliable \\
\hline
\end{tabular}

Profile Profile of Research Respondents

Table 6. Profile of Respondents by Job Category

\begin{tabular}{llll}
\hline No & Job Category & $\begin{array}{l}\text { Frequency } \\
\text { (Orang) }\end{array}$ & $\begin{array}{l}\text { Percentage } \\
(\mathbf{\%})\end{array}$ \\
\hline 1 & Employer & 39 & 39 \\
2 & $\begin{array}{l}\text { Workers Outside Employment } \\
\text { Relations or Independent Workers }\end{array}$ & 24 & 24 \\
3 & $\begin{array}{l}\text { Workers Excluding Workers Outside } \\
\text { Employment Relationships that Are } \\
\text { Not Receiving Wages }\end{array}$ & 37 & 37 \\
\hline Total & & $\mathbf{1 0 0}$ & $\mathbf{1 0 0}$ \\
\hline
\end{tabular}

Based on Table 6, it can be seen that in the occupational category, the respondents with the most or the majority were 39 employees with $39 \%$, while the minority occupational categories were 24 workers outside the employment relationship or $24 \%$ with $24 \%$.

Analysis of Multiple Linear Regression 
The Effect of Perceived Value and Personal Selling on Participants 'Decision on Employment BPJS Bengkulu Branch (Case Study on Wage Non-Recipient Category Customers)

Table 7. Coefficients

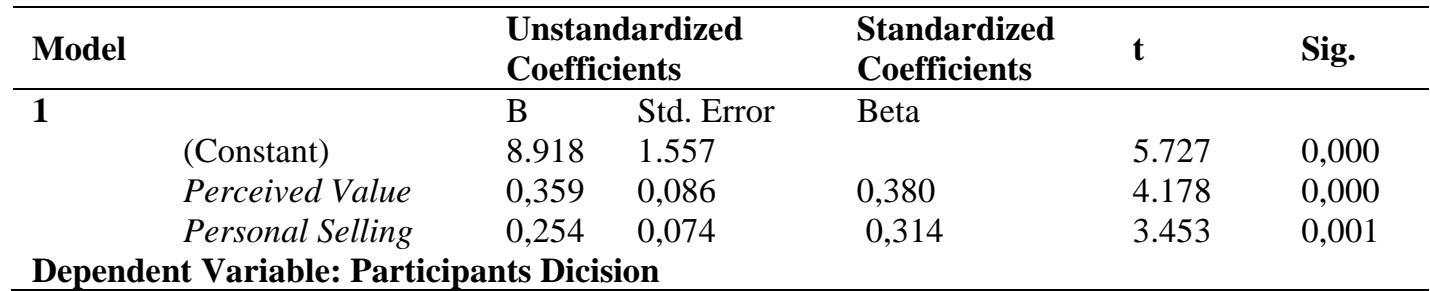

Table 8. Correlation Coefficient (R) and Determination Coefficient (R2)

\begin{tabular}{|c|c|c|c|c|c|}
\hline Model & $\mathbf{R}$ & R Square & $\begin{array}{l}\text { Adjusted } \\
\text { Square }\end{array}$ & $\mathbf{R}$ & $\begin{array}{l}\text { Std. Error of the } \\
\text { Estimate }\end{array}$ \\
\hline 1 & 0,587 & 0,345 & 0,331 & & 1.894 \\
\hline
\end{tabular}

Table 9. Feasibility Test Model (Test F)

\begin{tabular}{|c|c|c|c|c|c|c|}
\hline \multicolumn{7}{|c|}{ ANNOVA $^{b}$} \\
\hline Model & & $\begin{array}{l}\text { Sum of } \\
\text { Squares }\end{array}$ & Df & $\begin{array}{l}\text { Mean } \\
\text { Square }\end{array}$ & $\mathbf{F}$ & Sig. \\
\hline \multirow[t]{3}{*}{1} & Regression & 182.848 & 2 & 91.424 & 25.490 & $.000^{a}$ \\
\hline & Residual & 347.902 & 97 & 3.587 & & \\
\hline & Total & 530.750 & 99 & & & \\
\hline
\end{tabular}

Independent Variable: Perceived Value and Personal Selling

Dependent Variable: Participants Dicision

Individual Parameter Significance Test (t Test)

Table 10. Coefficients

\begin{tabular}{|c|c|c|c|c|c|c|}
\hline \multirow{2}{*}{$\begin{array}{l}\text { Model } \\
\mathbf{1}\end{array}$} & & \multicolumn{2}{|c|}{$\begin{array}{l}\text { Unstandardized } \\
\text { Coefficients }\end{array}$} & \multirow{2}{*}{$\begin{array}{l}\text { Standardized } \\
\text { Coefficients } \\
\text { Beta }\end{array}$} & \multirow[t]{2}{*}{$\mathbf{t}$} & \multirow[t]{2}{*}{ Sig. } \\
\hline & & B & Std. Error & & & \\
\hline & (Constant) & 8.918 & 1.557 & & 5.727 & 0,000 \\
\hline & Perceived Value & 0,359 & 0,086 & 0,380 & 4.178 & 0,000 \\
\hline & Personal Selling & 0,254 & 0,074 & 0,314 & 3.453 & 0,001 \\
\hline
\end{tabular}

\section{A. Discussion of Research Results}

1. Effect of Perceived Value (X1) on Participant Decisions (Y)

Based on the results of research and interviews with several respondents in the field, finding results that participants already felt that perceived value was an effective method as a way of BPJS Employment to provide a good positive signal to the participants' decisions. Perceived value is driven by the positive response from mouth to mouth which causes the decision of participants in choosing the services offered.

Based on the respondents' dominant data is the average age $>30$ years as many as 48 respondents and those who became the minority of respondents were women as many as 33 respondents. People who are participants in the BPJS Employment category Not Wage Recipients (BPU) state several things that need to be improved and improved again such as services provided by officers to consumers as participants in BPJS Employment. This is indicated by as many as 12 respondents stating Disagree. Besides that, a good impression after using the services provided by BPJS Employment. This is indicated by as many as 2 respondents stating Strongly Disagree and 5 respondents stated Disagree.

These findings are in accordance with the results of research from Henricus (2018); Zahrotun (2018); Muhammad (2015); Imroatul (2015); Stefanus (2015) supports that perceived value has a positive and significant effect on participants' decisions.

2. Effects of Personal Selling (X2) on Participant Decisions (Y)

Based on the results of research and interviews with several respondents in the field, finding results that participants had felt personal selling given or offered by BPJS Employment was good because personal selling provided information about a product or service offered to prospective customers that would have an impact on purchasing decisions.

Based on the respondents' dominant data is the average age > 30 years as many as 48 respondents and those who became the minority of respondents were women as many as 33 respondents. People who are participants in the BPJS Employment Non Wage Recipient category (BPU) state a number of things that need to be improved and further improved such as in the delivery of information, officers need to improve again in delivering information by providing clear information to participants as consumers. This is indicated by as many as 3 respondents stated Strongly Disagree and 9 respondents stated Disagree. In addition, BPJS Employment officers continue to try to provide confidence to participants for the services provided.

Published By:

Blue Eyes Intelligence Engineering

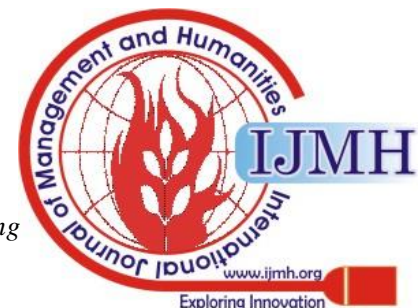


This is indicated by as many as 3 respondents stated Strongly Disagree and 9 respondents stated Disagree.

These findings are in accordance with the results of a study from Enike (2017); Muhammad (2017); Agustin (2016); Michael (2016); Tika (2016); Brilliant (2015); Driyanto (2015); Febryan (2014); Nency (2014) supports that personal selling has a positive and significant effect on participants' decisions. While the results of research from Silvia (2017) and Agustina (2014) show the results that personal selling has a positive and not significant effect on participants' decisions.

\section{Research Implications \\ Theoretical implications}

The theoretical implications of this research are expected to increase knowledge related to the decisions of BPJS Employment participants who can be seen from perceived value and personal selling. This can happen by showing that perceived value has a positive and significant effect on the decisions of BPJS Employment participants in the Non-Wage Recipient (BPU) category, while the personal selling variable has a positive and significant effect on the decisions of Bengkulu Branch BPJS Employment participants in the category of Non-Wage Recipients (BPU).

\section{Practical implications}

Based on the results of the research that has been done, the practical implications for the bound parties and subsequent researchers are expected so that this research can be used as an option to choose which variables are better used, depending on what is seen from the bound parties and further researchers to consider judging participants' decisions

\section{CONCLUSION}

1. Variable perceived value has a positive and significant effect on the decision of participants in the Bengkulu branch of the BPJS Employment Non Wage Recipient

2. The personal selling variable has a positive and significant effect on the decisions of participants in the Bengkulu branch of the BPJS Employment Non Wage

\section{SUGGESTIONS}

\section{For BPJS Employment}

a. Perceived value is good, but there are a number of things that need to be improved and further improved such as in the delivery of information, officers need to improve again in delivering information by providing clear information to participants as consumers. In addition, BPJS Employment officers continue to try to provide confidence to participants for the services provided.

b. Personal selling is good but there are some things that need to be improved and improved again, such as in the delivery of information, officers need to improve again in delivering information by providing clear information to participants as consumers. In addition, BPJS Employment officers continue to try to provide confidence to participants for the services provided.

\section{2. for Further Researchers}

For further researchers who are interested in researching this research, it is better to examine the company's image, (BPU) category. Recipient (BPU) category.

consumer loyalty and so on and can expand the sample to strengthen and produce good research.

\section{REFERENCES}

1. Ade, Sarwita. 2017. Pengaruh Kualitas Pelayanan dan Promosi Terhadap Keputusan Nasabah Untuk Menabung (Studi Kasus Pada Perumda BPR Majalengka). Jurnal Ilmiah Manajemen \& Akuntansi. Vol. 4 No. 1. ISSN: 2356-3923.

2. Agustin A. R., Setiyo. 2016. Pengaruh Personal Selling dan Sales Promotion Terhadap Keputusan Konsumen Manabung Britama di PT. Bank Rakyat Indonesia (Persero), Tbk Cabang Sidoarjo. Jurnal Universitas Negeri Surabaya.

3. Agustina M. K., Lisbeth M., Bode. 2014. Bauran Promosi Pengaruhnya Terhadap Keputusan Pembalian Motor Yamaha di PT. Hasjrat Abadi. Jurnal EMBA. Vol.2 No.3 September 2014, Hal. 1077-1088. ISSN 2303-1174.

4. Brilian R., Sem G. O., Sendry. 2015. Analisis Branding Strategy, Servicescape dan Personal Selling Terhadap Keputusan Pembelian Pada Dealer Yamaha Airmadidi. Jurnal EMBA. Vol.3 No.2 Juni 2015, Hal. 1-11. ISSN 2303-1174.

5. Danang, Sunyoto. 2013. Metodologi Penelitian Akuntansi. Bandung: PT. Refika Aditama Anggota Ikapi.

6. Daniel O., Azis F., Leonardo. 2015. Pengaruh Kualitas Pelayanan, Harga dan Promosi Terhadap Keputusan Pembelian Produk CKE Teknik Semarang. Jurnal Universitas Diponegoro.

7. Driyanto W., Bagus P., Hariadi. 2015. Pengaruh Personal Selling, Kualitas Produk Terhadap Keputusan Pembelian Melalui Kepuasan Konsumen di Toko Bagiak Pelangi Sari Banyuwangi. Jurnal Ilmiah Inovasi. Vol.15 No.3 Hal. 132-141, September-Desember 2015, ISSN 1411-5549.

8. Enike K., Joko. 2017. Pengaruh Periklanan dan Personal Selling Terhadap Keputusan Pembelian Produk IM3 Indosat Ooredo di Gerai Indosat Sales Area Kediri. Jurnal Aplikasi Bisnis. E-ISSN: 2407-5523. ISSN :2407-3741.

9. $\quad$ Febryan S., Zainul A., Fransisca. 2014. Pengaruh Bauran Promosi Terhadap Keputusan Pembelian (Survei pada Mahasiswa Jurusan Bisnis Angkatan 2010-2012 Fakultas Ilmu Administrasi Pengguna Indosat di Universitas Brawijaya). Jurnal Administrasi Bisnis (JAB) Vol. 9 No.2 April 2014. Universitas Brawijaya.

10. Ghozali, Imam. 2013. Aplikasi Multivariate dengan Program SPSS Edisi Ketujuh. Semarang: Badan Penerbit Universitas Diponegoro.

11. Henricus A. K., Farida. 2018. Pengaruh Product Knowladge, Perceived Quality, Perceived Risk, Perceived Value Terhadap Purchase Intention Pada Motor Kawasaki Ninja 250 F1 di Kota Semarang. Diponegoro Journal of Management. Volume 7, Nomor 4, Tahun 2016, Halaman 1-13. ISSN (Online): 2337-3792.

12. Imroatul, Khasanah. 2015. Analisis Pengaruh Preferensi Merek, Persepsi Kualitas dan Perceived Value Terhadap Keputusan Pembelian Sepeda Motor Yamaha Matik di Semarang. Jurnal Studi Manajemen \& Organisasi. Volume. 12 (2015) Desember 115 - 126.

13. Kotler, Keller. 2012. Manajemen Pemasaran. Edisi 12. Jakarta: Erlangga.

14. Kotler., Philip., Amstrong, Gary. 2014. Prinsip-prinsip Manajemen. Edisi 14, Jilid 1. Jakarta: Erlangga.

15. Michael N. Lontoh. 2016. Analisis Pengaruh Bauran Promosi Terhadap Keputusan Pembelian Mobil Toyota Pada PT. Hasjrat Abadi Manado Cabang Tendean. Jurnal Berkala Ilmiah Efisiensi. Volume 16 No. 01 Tahun 2016.

16. Mudrajat, Kuncoro. 2013. Manajemen Riset untuk Bisnis dan Ekonomi. Edisi 4. Jakarta: Erlangga.

17. Muhammad A., Harry S., I Made. 2015. Analisis Brand Awarness dan Perceived Value Terhadap Keputusan Pembelian (Studi Pada Konsumen Produk Deterjen Merek BOOM di Kabupaten Bojonegoro). Jurnal Sains Pemasaran Indonesia. Volume XV, Nomor 1, Mei 2016, Halaman 62-73.

18. Muhamad A., Indira. 2017. Pengaruh Bauran Promosi Terhadap Keputusan Pembelian Produk Oppo Smarthphone di Kota Bandung. e-Proceeding of Management. Vol.4, No.3 Desember 2017. ISSN: 2355-9357.

19. Nency M. N., Jantje L., Rudy. 2014. Periklanan, Penjualan Pribadi, Promosi Penjualan dan Publisitas Terhadap Keputusan Pembelian Pada Penerbit Andi Cabang Manado. Jurnal EMBA. Vol.2 No.4 Desember 2014, Hal. 578-588. ISSN 2303-1174.

Published By:

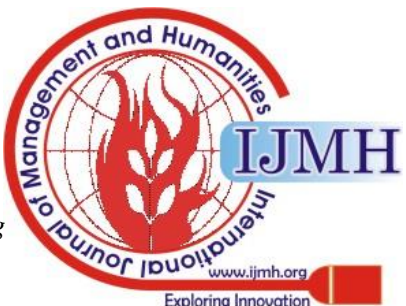


20. Sarah M. C., Maria. 2015. Pengaruh Kualitas Pelayanan, Promosi dan Lokasi Terhadap Keputusan Konsumen Menggunakan Hotel Baliem Pilamo di Wamena. Jurnal EMBA. Vol.3 No.3 Sept. 2015, Hal.959-970. ISSN 2303-11.

21. Silvia, Sofyan. 2017. Pengaruh Periklanan, Sales Promotion, Personal Selling dan Publicity Terhadap Keputusan Pembelian Produk Aksesoris Mobil (Studi Kasus Kilat Service Medan). Jurnal SMART. Vol. I No 1: 48-52, 2017 ISSN: 2549-5836.

22. Stefanus H. P., Djoko. 2015. Pengaruh Perceived Value Terhadap Keputusan Pembelian Smartphone Android Dengan Word of Mouth Sebagai Variabel Moderasi. Jurnal Ekonomi dan Kewirausahaan. Vol. 15 Edisi Khusus April 2015: 159.

23. Sugiyono. 2012. Metode Penelitian Administrasi, Bandung: CV. Alfabeta.

24. Tika H., Panjaitan. 2016. Pengaruh Personal Selling Terhadap Keputusan Pembelian (Studi Kasus PT Millenium Pharmacon Internasional, Tbk Cabang Bandung). e-Proceeding of Applied Science. Vol.2, No.2 Agustus 2016. ISSN: 2442-5826.

25. Tjiptono, Fandy dan Gregorius Chandra. 2012. Pemasaran Strategik. Yogyakarta:Andi

26. Wahid I., Rodhiyah. 2016. Pengaruh Kualitas Layanan dan Promosi Terhadap Keputusan Pembelian Pada E-Commerce Tokopedia di Kota Semarang. Jurnal Universitas Diponegoro.

27. Zahrotun N., Deliana W. L., Aries S., Ratna. 2018. Analisis Pengaruh Perceived Value, Citra Merek dan Kualitas Layanan Terhadap Minat Beli dan Keputusan Pembelian Dengan Word of Mouth Sebagai Variabel Moderasi (Studi Kasus Pengguna Kosmetik Merek Wardah di Universitas Diponegoro). Jurnal Universitas Diponegoro. ISSN 2337-4349. 